\title{
Action of Salt Formation on the Bifunctional Nature of 12-Molybdophosphoric Acid and Their Relationship to the Catalytic Activity
}

\author{
A. M. El-Awad and K. M. Abd El-Salaam \\ Chemistry Department, Faculty of Science, Assiut University Assiut, Egypt \\ Received February 17, 1987
}

Acidic properties and the catalytic activity of 12-molybdophosphates $\left(\mathrm{M}_{\mathrm{x} / \mathrm{n}}{ }^{\mathrm{n}+} \mathrm{H}_{3-\mathrm{x}} \mathrm{PMO}_{12} \mathrm{O}_{40} ; \mathrm{M}=\mathrm{Cu}^{2+}, \mathrm{Bi}^{3+}, \mathrm{Cr}^{3+}\right.$ and $\left.\mathrm{X}=1-3\right)$ have been studied. The results are discussed as the effect of these catalyst components on the partial charge on oxygen atom which is in a relation with the acidity. It is shown that the oxygen-hydrogen bond is weakened as the value of partial charge on oxygen $\left(-\delta_{0}\right)$ becomes more negative, while the vapor-phase dehydration activity of 2-propanol is explained on the basis of the reacting zone wideness taking into account the pseudo liquid phase nature of the heteropoly compounds. Correlation, the percentage conversion of 2-propanol with the fractional charge on molybdenum atom was successful to interpret the effect of the redox properties of these catalysts on their catalytic activity.

\section{INTRODUCTION}

Heteropoly acids have recently attracted much attention as catalysts for various industrial processes, such as oxidation, dehydration, esterification, and etheration. ${ }^{1}$ It has been reported that metal salts of heteropoly acids are more active and selective than the acid form in some acid-catalyzed reactions..$^{2-4}$

Relationships between catalytic activity and either the acidic or redox properties of these heteropoly compounds have been reported. Niiyama et al. ${ }^{5}$ obtained a fair correlation between the activity for alcohol dehydration and electronegativity of metal cations. Hayashi and Moffat found that the activity for methanol conversion was related to the partial charge on oxygen atom, ${ }^{6}$ while in considering the redox properties many schemes have been proposed ${ }^{7-10}$. Also, the participation of both the surface and bulk heteropoly salt molecules in the catalytic processes has been investigated by several workers. ${ }^{4,11-13}$

The present work, in an attempt to gain more insight into the bifunctional nature of the heteropoly salts (the acidic and redox properties), is concerned with an investigation of the acidity, dehydration activity and the electrical conductivity properties of the substituted 12-molybdophosphoric acid with $\mathrm{Bi}^{3+}, \mathrm{Cr}^{3+}$ and $\mathrm{Cu}^{2+}$ cations.

\section{EXPERIMENTAL}

$\mathrm{BDH}$ 12-molybdophosphoric acid was incorporated with the nitrates of $\mathrm{Cu}(\mathrm{II})$, $\mathrm{Cr}(\mathrm{III})$, and $\mathrm{Bi}(\mathrm{III})$. An aqueous solution containing the required amounts of these 
cations to form a series of salts having the general formula $\mathbb{I N}^{\mathrm{n}+}{ }_{\mathrm{x} / \mathrm{n}} \mathrm{H}_{3-\mathrm{x}} \mathrm{PMIO}_{12} \mathrm{O}_{40}$ (where $\mathrm{X}=1-3$ ) was added to a solution of 12-molybdophosphoric acid with vigorous strirring. The produced mixtures were dried over a water-bath, then the resultant solids were calcined at $300^{\circ} \mathrm{C}$ for $4 \mathrm{~h}$. in air stream.

The acidity of the samples was estimated by measuring the liberated amounts of acetic acid produced by the hydrolysis of ethyl acetate. The reaction was carried out in a water thermostate at $60^{\circ} \mathrm{C}$ using a $5.0 \%$ aqueous solution of ethyl actate. The extent of hydrolysis of ethyl acetate was determined by conventional titrimetry with $0.1 \mathrm{~N} \mathrm{NaOH}$ solution and phenolphthalein as an indicator.

The catalytic activity of the heteropoly compounds was measured via the dehydration reaction of 2-propanol, it was carried out using a conventional flow reactor. Purified air was used as carrier gas. The exit feed was analyzed using a 104 series PYE UNICAM gas Chromatograph with a polyethylene glycol $20 \%$ column coated on celite.

Electrical conductivity measurements were carried out with a conductivity cell described by Chapman et al. ${ }^{14}$. The temperature was controlled with a Gallenkamp temperature controller. Voltage was obtained via a 240A Keithley Instruments supply and the current was measured with a $410 \mathrm{~A}$ picoammeter (Keithley Instruments).

\section{RESULTS AND DISCUSSION}

Acidity measurements. - For the prepared catalysts, the acidity was esti-mated using the hydrolysis of ethyl acetate, since the reaction is known to be catalyzed by Brönsted acid sites. ${ }^{15}$ Therefore, kinetic studies were made of this reaction over various catalysts as well as in different concentrations of hydrochloric acid solution for comparison. In all cases, the hydrolysis rate obeyed good first-order kinetics with respect to the concentration of ethyl acetate. The representative plots of the first-order kinetics over several catalysts are shown in Figure 1. During the hydrolysis in various concentrations of $\mathrm{HCl}$ solution, the first-order rate constant $\left[k_{\mathrm{HCl}}\left(\mathrm{min}^{-1}\right)\right]$ was proportiona] to the concentration of $\mathrm{HCl}$ and was expressed as

$$
k_{\mathrm{HCl}}=3.72 \times 10^{-3} c_{\mathrm{HCl}}
$$

Hence, the acidities can be expressed as the amount of $\mathrm{HCl}$ required to attain the same reaction rates over the studied acid catalysts as appear in Table I.

TABLE I

The Specific Rata Constants of Ethyl Acetate Hydrolysis, Acidity of the Catalysts (Expressed in meq $\mathrm{HCl}$ ), \%/Conversion of 2 -Propanol at $1500^{\circ} \mathrm{C}$, and the Calculated Fractional Charge on Oxygen $\left(\delta_{\mathrm{e}}\right)$

\begin{tabular}{|c|c|c|c|c|c|}
\hline Catalyst & $\begin{array}{l}\text { Suggested } \\
\text { formulation }\end{array}$ & $\begin{array}{c}\begin{array}{c}\text { Rate } \\
\text { constant }\end{array} \\
\begin{array}{c}10^{3} \times k \\
\left(\mathrm{~min}^{-1} \cdot \mathrm{g}^{-1}\right)\end{array}\end{array}$ & $\%$ Conv. & $\frac{\text { Acidity }}{\mathrm{meq} \cdot \mathrm{g}^{-1}}$ & $\delta_{0}$ \\
\hline $\begin{array}{l}\text { I } \\
\text { II } \\
\text { III } \\
\text { IV } \\
\mathrm{V} \\
\mathrm{VI} \\
\text { VII } \\
\text { VIII } \\
\text { IX } \\
\mathrm{X}\end{array}$ & 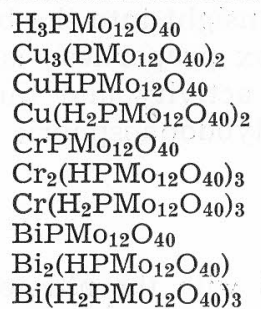 & $\begin{array}{l}2.555 \\
2.531 \\
2.464 \\
2.236 \\
1.750 \\
2.001 \\
2.200 \\
1.15 \\
1.640 \\
2.156\end{array}$ & $\begin{array}{l}16.24 \\
24.10 \\
21.07 \\
18.18 \\
14.2 \\
10.5 \\
8.2 \\
29.17 \\
30.77 \\
36.9\end{array}$ & $\begin{array}{l}0.687 \\
0.680 \\
0.662 \\
0.601 \\
0.470 \\
0.538 \\
0.59 \\
0.309 \\
0.441 \\
0.579\end{array}$ & $\begin{array}{l}-0.1966 \\
-0.1968 \\
-0.19675 \\
-0.1967 \\
-0.1954 \\
-0.1958 \\
-0.1962 \\
-0.1945 \\
-0.1952 \\
-0.1959\end{array}$ \\
\hline
\end{tabular}




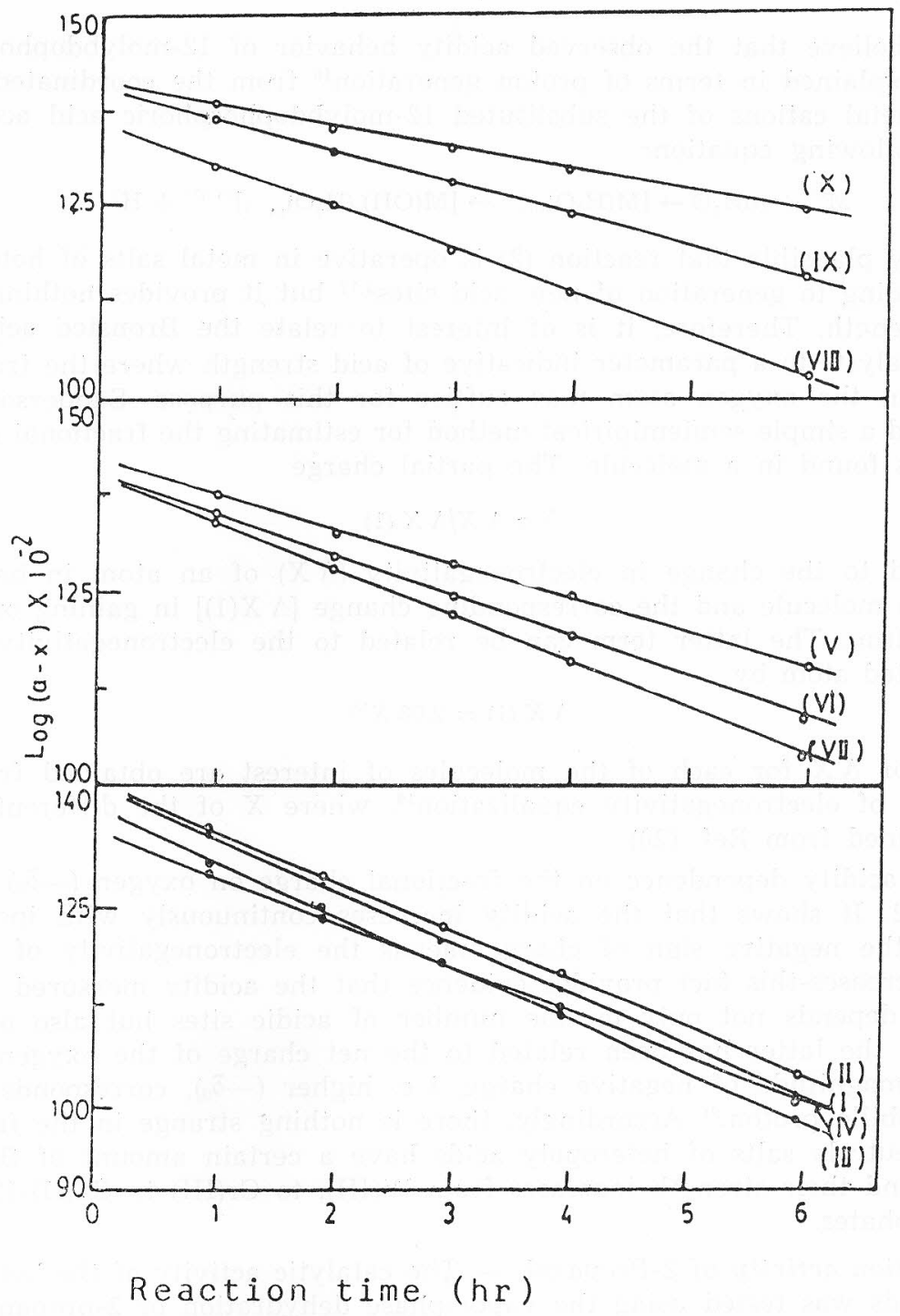

Figure 1. Representative plots of first order kinetics of ethyl acetate hydrolysis over pure (I) and substituted 12-molybdophosphoric acid (II-X).

The data illustrated in Table $\mathrm{I}$ show that: $\mathrm{i}$ - The acidity of $\mathrm{H}_{3} \mathrm{PMO}_{12} \mathrm{O}_{40}$ continuously decreases by a stepwise replacement of $\mathrm{H}^{+}$by $\mathrm{Bi}^{3+}$ or $\mathrm{Cr}^{+}$cations. ii - Although substitution of one proton of the heteropoly acid with the equivalent amount of $\mathrm{Cu}^{2+}$ reduces the acidity, but it was found that an increase of $\mathrm{Cu}^{2+}$ content raises the acidity again. This means, that the number of available sites for reaction (protons) is higher than expected owing to the partial salt formation. Also, the acidic nature is still present even with the formation of "neutral« salts. 
We believe that the observed acidity behavior of 12-molybdophosphates can be explained in terms of proton generation ${ }^{16}$ from the coordinated water to the metal cations of the substituted 12-molybdophosphoric acid according to the following equation:

$$
\mathrm{M}^{\mathrm{n}+}+\mathrm{mH}_{2} \mathrm{O} \rightarrow\left[\mathrm{M}\left(\mathrm{H}_{2} \mathrm{O}\right)_{\mathrm{m}}\right]^{\mathrm{n}+} \rightarrow\left[\mathrm{M}(\mathrm{OH})\left(\mathrm{H}_{2} \mathrm{O}\right)_{\mathrm{m}-1}\right]^{(\mathrm{n}-1)+}+\mathrm{H}^{+} \ldots
$$

It is very plausible that reaction (2) is operative in metal salts of heteropoly acids leading to generation of new acid $\operatorname{sites}^{5,17}$ but it provides nothing about their strength. Therefore, it is of interest to relate the Bronsted acidity of these catalysts to a parameter indicative of acid strength where the fractional charge on the oxygen atom may suffice for this purpose. Sanderson ${ }^{18}$ has developed a simple semiemipirical method for estimating the fractional charges on atoms found in a molecule. The partial charge

$$
\delta=\Delta X / \Delta X(1)
$$

is related to the change in electronegativity $(\Delta X)$ of an atom in becoming part of a molecule and the corresponding change $[\Lambda X(1)]$ in gaining or losing one electron. The latter term can be related to the electronegativity, $X$, of the isolated atom by

$$
\Delta X(1)=2.08 X^{1 / 2}
$$

values for $\Delta X$ for each of the molecules of interest are obtained from the principle of electronegativity equalization ${ }^{19}$, where $X$ of the different atoms are obtained from Ref. (20).

The acidity dependence on the fractional charge on oxygen $\left(-\delta_{0}\right)$ is seen in Fig. 2. It shows that the acidity increases continuously with increasing $\left(-\delta_{0}\right)$ - the negative sign of charge means the electronegativity of oxygen atom decreases-this fact provides evidence that the acidity measured for our samples depends not only on the number of acidic sites but also on their strength; the latter has been related to the net charge of the oxygen where smaller magnitude of negative charge, i. e. higher $\left(-\delta_{0}\right)$, corresponds to the more mobille proton. ${ }^{21}$ Accordingly, there is nothing strange in the fact that even »neutral « salts of heteropoly acids have a certain amount of Brönsted acidity and their strength increases from $\mathrm{Bi}$ (III), to $\mathrm{Cr}$ (III) to $\mathrm{Cu}$ (II)-12-molybdophosphates.

Dehydration activity of 2-Propanol. - The catalytic activity of the heteropoly compounds was tested using the vapor-phase dehydration of 2-propanol over various catalysts. The reaction conditions were as follows: catalyst weight $500 \mathrm{mg}$; reaction temperature $150{ }^{\circ} \mathrm{C}$; concentration of 2-propanol $4.2 \%$ in air, total flow rate $180 \mathrm{ml}(\mathrm{NTP}) / \mathrm{min}$. The product were propylene and water. As shown in Table I, the percentage conversion of 2-propanol is inversely related to the acidity of both $\mathrm{Bi}$ (III) and $\mathrm{Cr}$ (III) heteropoly salts. On the other hand, there is a proportional relationship between the acidity and the dehydration activity for $\mathrm{Cu}$ (II) salts. These findings mean that when the kind of counter cation is changed the activity of the $\mathrm{M}_{\mathrm{x} / \mathrm{n}}{ }^{\mathrm{n}} \mathrm{H}_{3-\mathrm{x}} \mathrm{PMO}_{12} \mathrm{O}_{40}$ catalysts for dehydration of 2-propanol varies remerkably. Also, when the kind of counter cation is fixed and the amount of counter cation is changed, the dehydration activity varies in a way indicating that the activity is affected not only by the acidity of the catalysts, but also by other functions. 


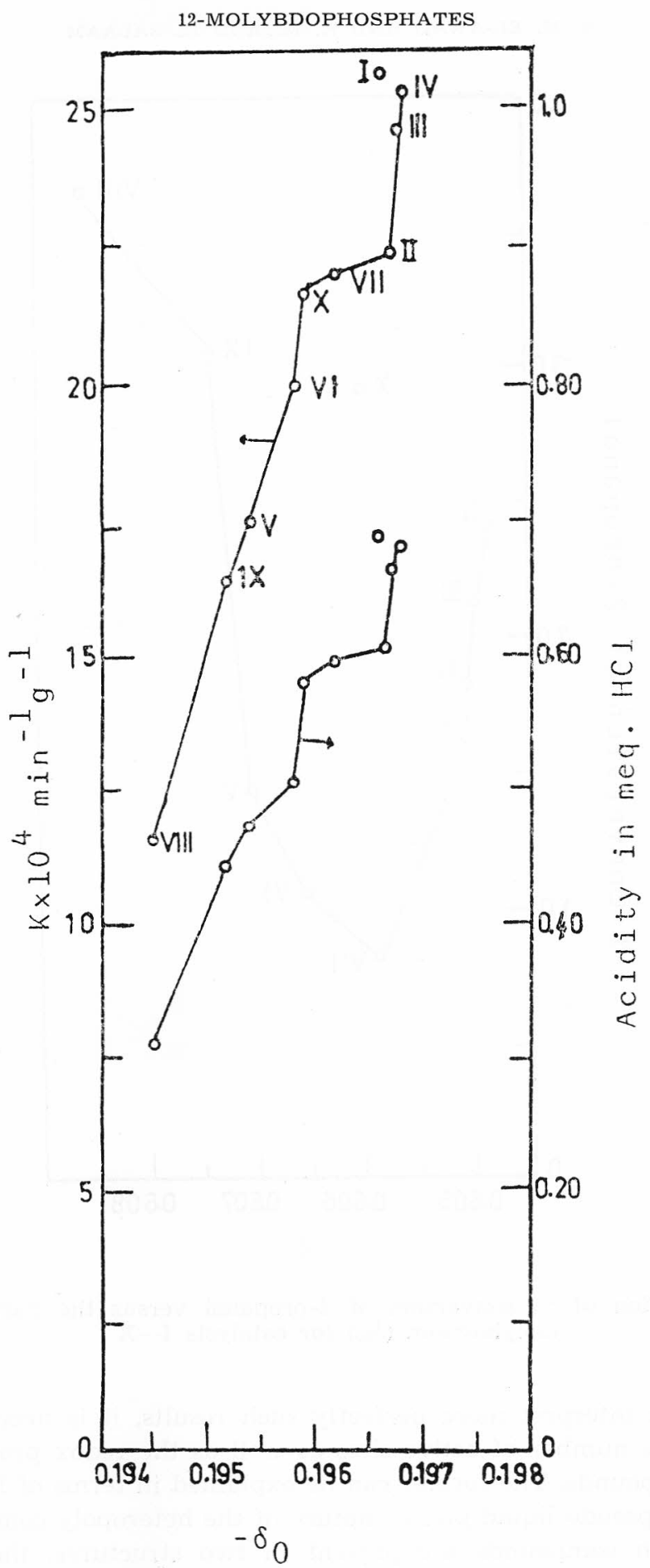

Figure 2. Specific rate constants of ethyl acetate hydrolysis and the acidity expressed in meq. $\mathrm{HCl}$ versus the partial charge on oxygen $\left(-\delta_{0}\right)$ for catalysts $\mathrm{I}-\mathrm{X}$. 


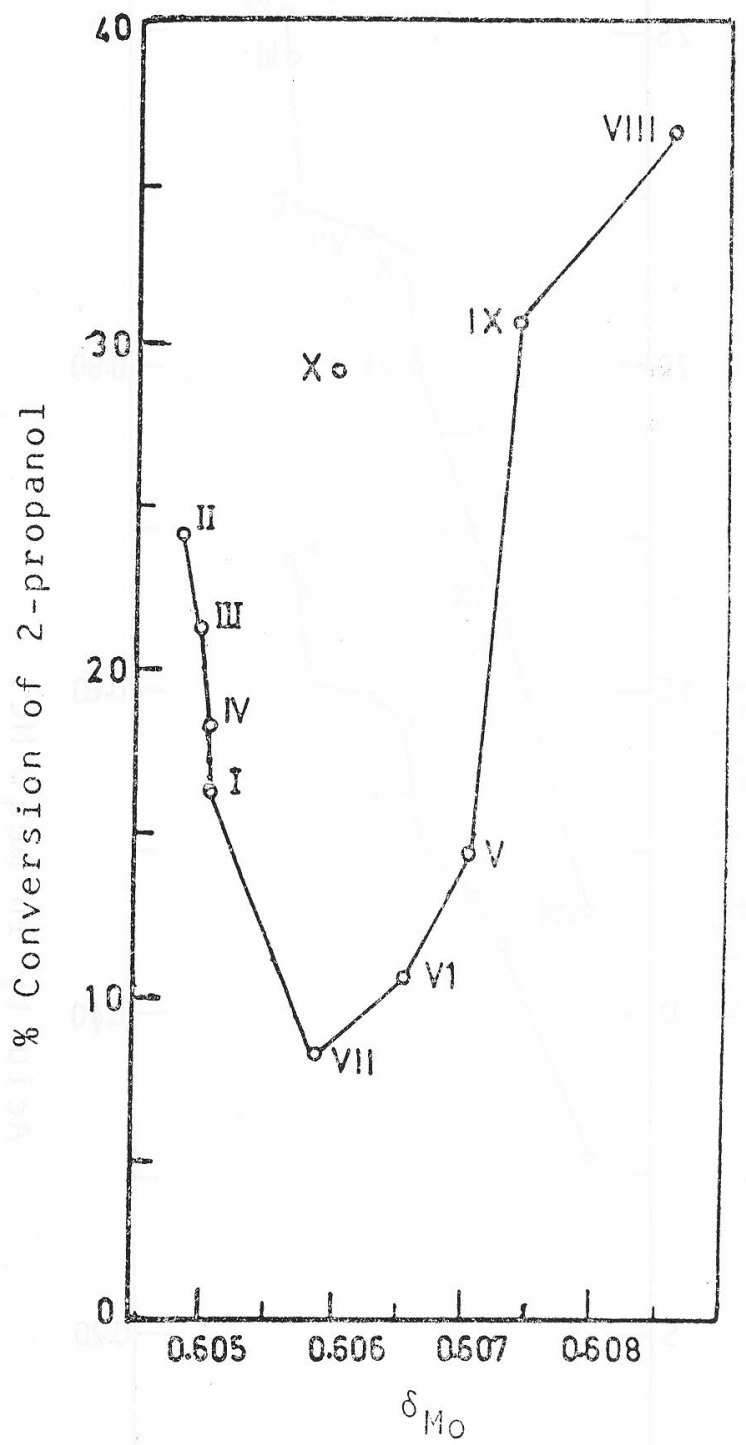

Figure 3. Variation of $\%$ conversion of 2-propanol versus the partial charge on molybdenum $\left(\delta_{\text {мо }}\right)$ for catalysts $\mathrm{I}-\mathrm{X}$

In order to interpret more perfectly such results, it is necessary to take into account the number of active sites as well as the redox properties of the heteropoly compounds. The former can be explained in terms of Misono et al. ${ }^{22}$ description of »pseudo liquid phase nature of the heteropoly compounds. They stated that such compounds are present in two structures, the first is the stable "primary structure (the Keggin unit, $\mathrm{PMO}_{12} \mathrm{O}_{40}{ }^{3-}$ ) and the second is subjected to easy rearrangement and is called the "secondary structure (the 
three-dimensional arrangement of the heteropoly anion, water and the counter cation). These characteristics make heteropoly compounds behave like a solution, and in some cases the catalytic reactions proceed in the interstitial space of the bulk ${ }^{13}$. Accordingly, the higher activity of $\mathrm{Bi}$ (III) salts may be attributed to an increase of the reacting zone wideness available for the catalytic reaction, more than takes place for the other salts. This opinion will be confirmed by electrical conductivity measurements.

A second explanation based on the redox properties ${ }^{23,24}$ of 12 -molybdophosphates is obtained by correlating the percentage conversion of 2-propanol with the fractional charge on molybdenum cation as the effective component. The results presented graphically in Figure 3, show that: i -- Substitution with unreducible cations increases the dehydration activity with increasing $\delta_{\text {Mo, }}$ ii - An inverse situation is obtained in case of the substitution with reducible cations. Taking into account that increasing $\delta_{M o}$ means increasing the electron affinity of $\mathrm{MIO}^{6+}$ and we suggest that the reaction proceeds according to the following steps: i - Attacking the $\mathrm{MI}^{6+}$ cations by alcoholic $\mathrm{OH}$ groups, simultaneously $\mathrm{C}-\mathrm{OH}$ bond becomes weaker and $\mathrm{Mro}^{6+}$ will be in a slightly reduced state $\left(\mathrm{Mo}^{\mathrm{n}+<6+}\right)$, ii - Complete separation of alcoholic $\mathrm{OH}^{-}$group, leaving the alcohol molecule as a carbonium ion to be attached to $\mathrm{Mo}^{6+}$ in a reduced state, $\mathrm{Mo}^{5+}$. iii - Reoxidation of $\mathrm{Mo}^{5+}$ accompanied by separation of the hydroxyl ion to form with the released hydrogen ion a molecule of water.

From this proposed mechanism two contradicitive steps appear to be involved, the first depends on the reducibility of $\mathrm{Mo}^{6+}$, while the second depends on the reoxidizability of $\mathrm{Mo}^{5+}$. As regards the relationship between $\delta_{\text {Mo }}$ and the dehydration activity (Figure 3) it is easy to decide that the reaction is predominantly affected by step 1 which is enhanced by increasing $\delta_{\mathrm{Mo}}$ as found for $\mathrm{Cr}$ (III), and $\mathrm{Bi}$ (III)-molybdophosphates. On the other hand, an additional factor for the activation of step 1 is obtained from the observable higher catalytic activity for $\mathrm{Cu}$ (II) salts, which show a higher $\%$ conversion of 2-propanol than corresponding to $\delta_{\text {Mo }}$ of these salts. This reflects a certain role of the presence of a reducible cation on the catalytic activity. The two explanation mentioned above may be supported by electrical conductivity measurements.

Electrical Conductivity Measurement. - It was carried out on the three »neutral salts (compounds II, V, VIII) as well as on the free heteropoly acid (comp. 1); the initial conductivities at $150^{\circ} \mathrm{C}$ in a flow of air were $1.26 \times 10^{-10}$, $0.59 \times 10^{-10}, 1.20 \times 10^{-10}$ and $43.48 \times 10^{-10} \Omega^{-1} \mathrm{~cm}^{-1}$, respectively. When 2-propanol vapor was introduced the conductivity increased and attained constant values of $3.02 \times 10^{-10}, 0.91 \times 10^{-10}, 3.80 \times 10^{-10}$, and $87.1 \times 10^{-10} \Omega^{-1} \mathrm{~cm}^{-1}$, respectively, after $2 \mathrm{~h}$. The data illustrated above are represented as $\left(\sigma_{\mathrm{i}} / \sigma_{0}-1\right)$ - where $\sigma_{0}$ is the conductivity before admission of 2-propanol and $\sigma_{\mathrm{i}}$ is that measured at time $t_{\mathrm{i}}$ after admission of alcohol-versus time, as shown in Figure 4.

From Figure 4, complete agreement between our opinion on the effect of the reacting zone wideness on the catalytic activity and the conductivity behavior can be seen from the order of increase of the relative conductivity $\sigma_{\mathrm{i}} / \sigma_{\mathrm{o}}$ which has the same sequence of increasing the catalytic activity. This result provides evidence of the parallel relationship between the conductivity 


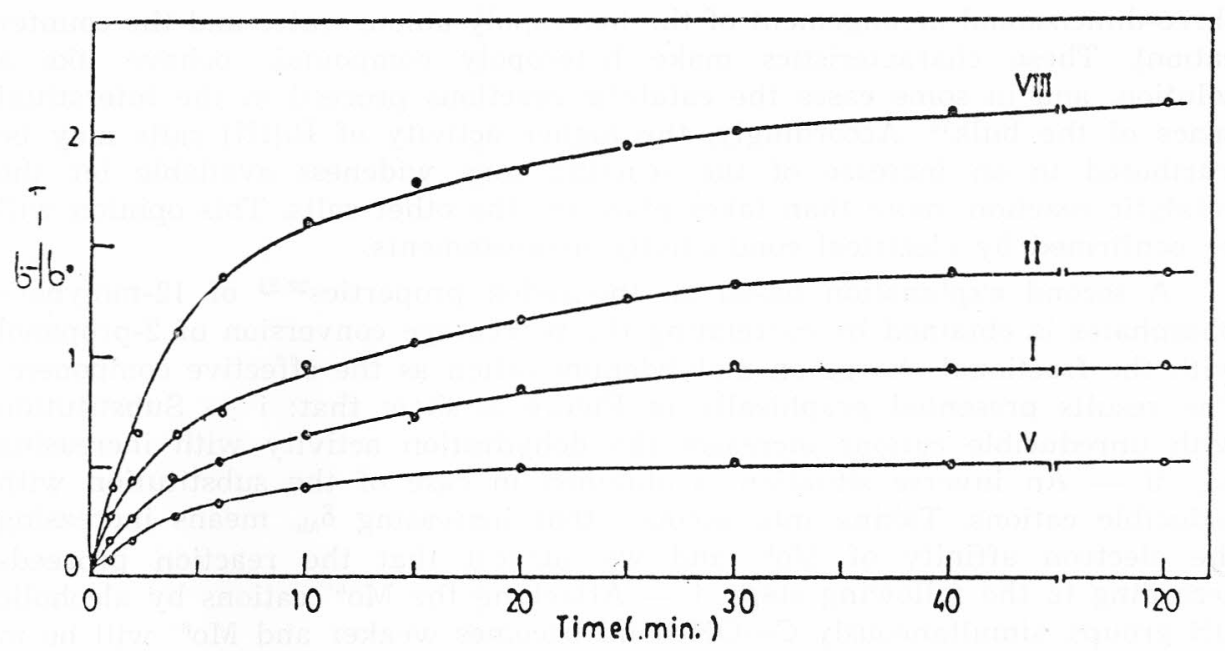

Figure 4. Relative change of electrical conductivity versus time of amdission of 2-propanol over catalysts I, II, V, and VIII.

and the number of active sites which increase with an increase of the reacting zone wideness, showing more current carriers available for conduction. Further support can be obtained from the activation energy calculations using equation (5).

$$
\sigma=\sigma_{\mathrm{o}} \exp (-E / R T)
$$

where $\log \sigma$ values have been plotted against the reciprocal absolute temperature (Figure 5); the slope of the obtained lines was considered to give the activation energy, $E^{25}$.

As appears in Table II, the order of decreasing $\Delta E$ have the sequence compound II $<$ VIII $<\mathrm{I}<\mathrm{V}$, exhibiting the same order of decreasing the catalytic activity, where compound VIII $>\mathrm{I}>\mathrm{V}$ the only exception is sample II. It shows the lowest value of $\Delta E$ confirming the acceleration role of the reducible cations on the electrons mobility.

TABLE II

Activation Energy Values for 12-Molybdophosphoric Acid and its Neutral Salts With $\mathrm{Bi}(\mathrm{III}), \mathrm{Cr}(\mathrm{III})$, and $\mathrm{Cu}(\mathrm{II})$.

\begin{tabular}{lccc}
\hline \multicolumn{1}{c}{ Catalyst } & $\begin{array}{c}E / \text { ev } \\
\text { in air flow }\end{array}$ & $\begin{array}{c}E / \text { ev after } \\
\text { admission } \\
\text { of }\end{array}$ & $\Delta E /$ 2-propanol \\
\hline $\mathrm{H}_{3} \mathrm{PMI}_{12} \mathrm{O}_{40}$ & 0.586 & 0.688 & 0.102 \\
$\mathrm{BiPMo}_{12} \mathrm{O}_{40}$ & 0.639 & 0.700 & 0.061 \\
$\mathrm{CrPMo}_{12} \mathrm{O}_{40}$ & 0.527 & 0.791 & 0.264 \\
$\mathrm{Cu}_{3}\left(\mathrm{PMO}_{12} \mathrm{O}_{40}\right)_{2}$ & 0.688 & 0.703 & 0.015 \\
\hline
\end{tabular}




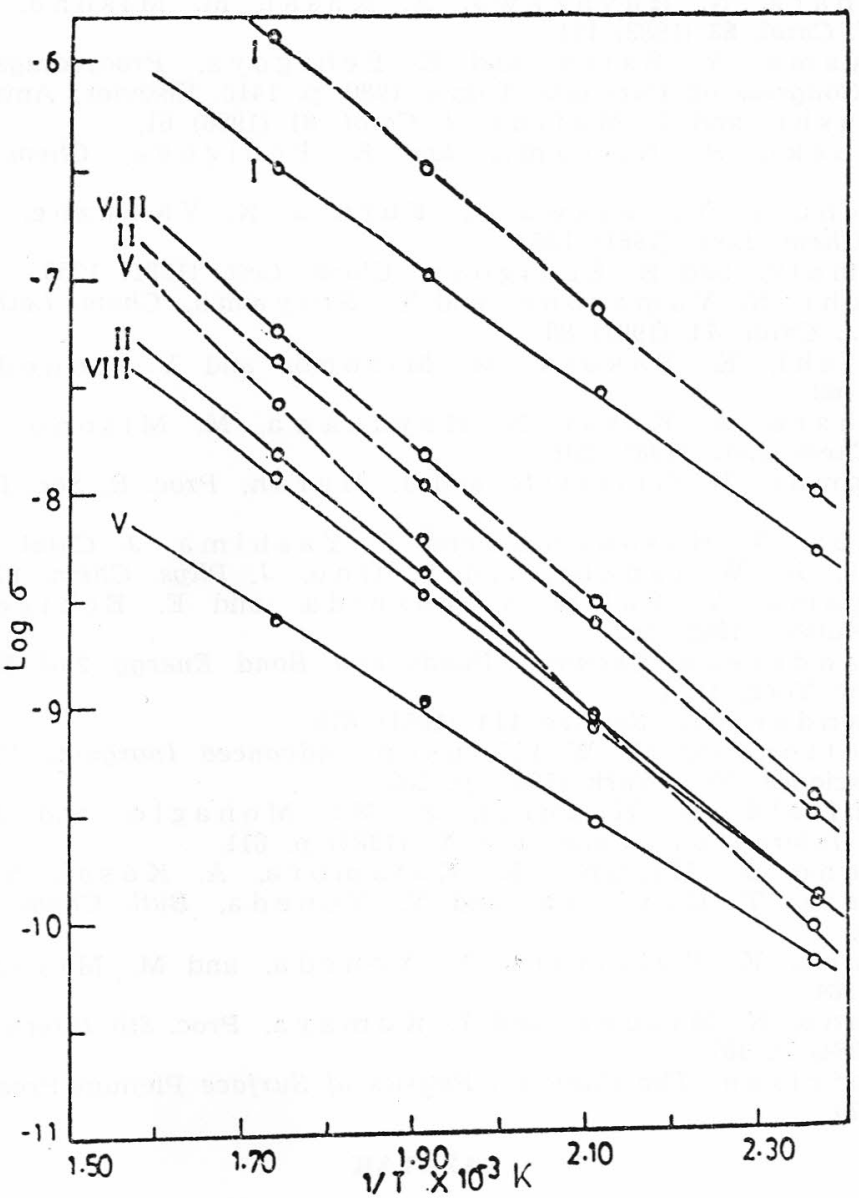

Figure 5. Variation of $\log \sigma$ versus $1 / \mathrm{T}$ for catalysts I, II, V, and VII in air (solid lines), and with admission of 2-propanol (dotted lines).

Finally, our conclusion is that the dehydration reaction of 2-propanol over 12-molybdophosphates is affected by the reacting zone wideness, i.e. the number of active sites, and the activity of these sites is essentially dependent on the acidic nature of the catalyst and the redox properties of $\mathrm{Mo}^{6+}$, the former is related to the $\delta_{0}$ while the latter is related to $\delta_{\text {Mo. }}$.

\section{REFERENCES}

1. T. Ohara, Shokubai 19 (1977) 157; K. Onoue, Y. Mizutani, S. Akiy a ma, and Y. Izumi, Chemtech, July (1978), p. 432.

2. T. B a ba, J. Sakai, and Y. O no, Bull. Chem. Soc. Jpn. 55 (1982) 2675; Y. O no, T. Baba, J. Sakai, and T. Kei i, J. Chem. Soc. Chem. Commun. (1982) 400.

3. T. Hibi, T. Okuhara, M. M isono, and Y. Yoneda, Chem. Lett. (1982) 1275. 
4. T. Okuhara, N. Hayakawa, A. Kasai, M. Misono, and Y. Yoned a, J. Catal. 83 (1983) 121.

5. H. Niiyama, Y. Saito, and E. Echigoya, Proceedings, 7th, International Congress on Catalysis. Tokyo, 1980, p. 1416. Elsevier; Amsterdam, 1981.

6. H. H a y a si, and J. M off a t, J. Catal. 81 (1983) 61.

7. H. Tsuneki, H. Niiyama, and E. Echigova, Chem. Lett. (1978) $654 ; 1183$.

8. K. Eguchi, Y. Toyozawa, K. Furuta, N. Yamazoe, and T. Seiy a m a, Chem. Lett. (1981) 1253 .

9. M. A kimoto, and E. Echigoya, Chem. Lett. (1981) 1759.

10. K. Eguchi, N. Yamazone, and T. Seiy a m a, Chem. Lett. (1982) $1341 .$.

11. M. A i, J. Catal. 71 (1981) 88.

12. Y. Konishi, K. Sakata, M. Misono, and Y. Yoneda, J. Catal. 77 (1982) 169.

13. T. Okuhara, A. Kasai, N. H a y a k a a, M. Misono, and Y. Yoned a, Chem. Lett. (1981) 391.

14. P. Cha pman, R. Griffith, and J. Marsh, Proc. R. Soc. London, (1954) $224,419$.

15. S. Namba, N. Hosonuma, and T. Yashima, J. Catal. 72 (1981) 16.

16. T. Baba, H. W a tanabe, and Y. O no, J. Phys. Chem. 87 (1983) 2406.

17. H. Niiyama, Y. Saito, S. Yoshida, and E. Echigoya, Nippon Kagaku Kaishi, (1982) 569.

13. R. T. Sanderson Chemical Bonds and Bond Energy 2nd Ed., Academic press, New York, 1976.

19. R. T. S a nderson, Science 114 (1951) 670.

20. F. A. Cotto $\mathrm{n}$ and $\mathrm{G}$. Will $\mathrm{kinson}$, Advanced Inorganic Chemistry 2 nd. Ed. Interscience, New York (1967) p. 103.

21. J. Highfield, B. Hodnett, J. Mc Monagle, and J. Moffat, Proc. 8th Intern. Cong. Catal. Vol. V, (1984) p. 611.

22. M. Misono, N. Mizuno, K. Katamura, A. Kasai, Y. Konishi, K. Sakata, T. Okuhara, and Y. Yoneda, Bull. Chem. Soc. Jpn, 55 (1982) 400 .

23. N. Mizuno, K. Katamura, Y. Yoneda, and M. Misono, J. Catal, 83 (1983) 384.

24. M. Misono, N. Mizuno, and T. Kom a y a, Proc. 8th Intern. Cong. Catal. Vol. V (1984) P. 487.

25. S. R. Morrison, The Chemical Physics of Surface Plenum Press, New York, (1977) p. 70.

\section{SAZ̆ETAK}

\section{Katalitička aktivnost 12-molibdofosfornib kiselina}

A. M. El-Awad i K. M. Abd El-Salaam

Ispitivani su 12-molibdofosfati općeg sastava $\mathrm{M}^{\mathrm{n}+}{ }_{\mathrm{x} / \mathrm{n}} \quad \mathrm{H}_{3-\mathrm{x}} \quad \mathrm{PMO}_{12} \mathrm{O}_{40}$ gdje je $\mathrm{M}=\mathrm{Cu}^{2+}, \mathrm{Bi}^{3^{+}}, \mathrm{Cr}^{3^{+}} \mathrm{i} \mathrm{x}=1-3$. U radu se objašnjava utjecaj različitih fizičko-kemijskih osebina tih spojeva kao što je na primjer parcijalni naboj na kisikovom atomu, redoks potencijal itd. na katalitičku sposobnost proučavanih spojeva. 